\title{
1970 PROGRAM
}

\section{AMERICAN SOCIETY FOR \\ CLINICAL INVESTIGATION, INC. \\ 62ND ANNUAL MEETING}

Including programs for

American Federation for Clinical Research, Inc.

The Association of American Physicians

\author{
MONDAY, MAY 4 \\ PENNSYLVANIA ROOM, HADDON HALL
}

ATLANTIC CITY 


\title{
American Society for Clinical Investigation, Inc.
}

\author{
62 ND ANNUAL MEETING
}

\author{
MONDAY, MAY 4
}

M OR N I N G

9:00 a.m., Pennsylvania Room, Haddon Hall

FIRST BUSINESS SESSION

THE PRESIDENT'S ADDRESS

\section{SCIENTIFIC SESSION}

Chairman: Dr. Lloyd H. Smith, Jr.

(The presentation of each paper will be limited to $10 \mathrm{~min}$. )

1. Abnormal Alpha Cell Function in Diabetes. W. A. Muller,* G. R. Faloona,* and R. H. Unger, Dallas, Tex. (218)

2. Evidence for a Glucose-Alanine Cycle: Amino Acid Metabolism during Muscular Exercise. P. Felig* and J. Wahren,* New Haven, Conn., and Stockholm, Sweden (introduced by P. K. Bondy**). (90)

3. The Induction of Human Muscle Mitochondrial Proliferation and Increased Glycogen and Triglyceride Synthesis by Long-Term Exercise. F. A. Short,* R. Ross,* L. A. Cовв,* and T. E. Morgan, Seattle, Wash. (282)

4. A New Biochemical Lesion in Acute Intermittent Porphyria: Deficiency of Steroid $\Delta^{4}-5 \alpha$-Reductase Activity. P. N. Gillette,* H. L. Bradlow,* T. F. Gallagher,* and A. Kappas, New York. (110)

5. The Source of Abnormal Bile in Patients with Cholesterol Gallstones. D. M. SMall and S. Rapo,* Boston, Mass. (286)

6. Isolation of a Tumor Factor Responsible for Neovascularization. J. Folkman,* E. Merler,* C. Abernathy,* and G. Williams,* Boston, Mass. (introduced by F. S. Rosen). (95)

7. New Species of Hybridizable Nuclear RNA in Breast Cancer Cells. R. W. Turkington,* Durham, N. C. (introduced by R. W. Rundles). (313)

\footnotetext{
* Denotes nonmember, ASCI, AFCR, or AAP.

** Denotes emeritus member ASCI or senior member AFCR.

Names with no following symbol are active members of the society to which the abstract was submitted.

( ) Abstract number.

¥ The President gratefully acknowledges the valuable assistance of the Subsection Chairmen in the selection of this program.
}

8. Regulation of Cell-Free Hemoglobin Synthesis. D. ShaFritz,* J. Gilbert,* P. Prichard,* and F. Anderson,* Bethesda, Md. (introduced by J. E. Rall**). (275)

9. Whole-Mount Electron Microscopy of Human Meiotic Chromosomes. D. E. Comings and T. A. Orada,* Duarte, Calif. (66)

10. Survival of Cultured Fibroblasts from Xeroderma Pigmentosum and Normals after Ultraviolet Irradiation. S. Goldstern,* Hamilton, Ontario, Canada (introduced by J. W. Littlefield). (114)

11. Mutation Rate of Immunoglobulin Producing Mouse Myeloma Cells In Vitro. P. Coffino* and M. D. ScHARFF, New York. (61)

12. Changes of Action Potential Shape after Chronic Cardiac Denervation. A. Wallace, J. Dorsey,* and J. Miller,* Durham, N. C. (320)

\section{A F T ER NOON}

2:00 p.m., Pennsylvania Room, Haddon Hall

SECOND BUSINESS SESSION

\section{SCIENTIFIC SESSION}

Chairman: Dr. Franklin H. Epstein

13. D-Glucose Binding by a Brush Border Fraction from Rabbit Renal Tubules. D. Busse,* L. J. Elsas,* and L. E. Rosenberg, New Haven, Conn. (47)

14. Evidence for a Primary Disturbance of Membrane Transport in Bartter's Syndrome and Liddle's Syndrome. J. Gardner,* A. Lapey,* A. Simopoulos,* and E. Bravo,* Bethesda, Md. (introduced by R. S. Gordon, Jr.). (103)

15. Thromboembolism and Oral Contraceptive Medication. N. Alkjaersig,* A. P. Fletcher, ** and R. Burstein,* St. Louis, Mo. (7)

16. The Role of Cyclic Adenosine-3',5'-Monophosphate and Prostaglandin in Platelet Aggregation. S. M. WoLfE,* J. Muenzer,* and N. R. Shulman, Cleveland, Ohio, and Bethesda, Md. (335)

17. Cholestyramine Enhances Digitalis Excretion and Protects Against Lethal Intoxication. J. H. CALdwell* and N. J. Greenberger,* Columbus, Ohio (introduced by A. M. Weissler). (50) 
18. Isolation of a New Progesterone "Receptor" from Oviduct Target Tissue. B. W. O'MALLEY* and M. M. Rubin,* Nashville, Tenn., and Bethesda, Md. (introduced by C. R. Park**). (227)

19. Treatment of Paget's Disease with Salmon Calcitonin. F. R. Singer,* R. M. Neer,* J. A. Parsons,* S. M. Krane, and J. T. Potts, JR., Boston, Mass. (284)

20. Low Oxygen Pressure: a Cause of Erythrocyte Membrane Rigidity. P. L. LACELLE* and R. I. WEED, Rochester, N. Y. (174)

21. Anti-Inflammatory Effects of Estrogen. P. BodEL,* G. M. Dillard,* S. Kaplan,* and S. Malawista,* New Haven, Conn. (introduced by L. R. Freedman). (32)
22. Macrophage Augmentation of Interferon Production in Cultures of Human Lymphocytes. L. B. Epstein,* M. J. Cline, and T. C. Merigan, San Francisco and Palo Alto, Calif. (86)

23. Defective Cellular Immunity in Uremia: Depression of Reactivity of Lymphocytes to Phytohemagglutinin by Uremic Sera. W. M. NewberRY* and J. P. SANFord, Dallas, Tex. (224)

24. Herpes-Like Virus Infection in Sarcoidosis. Y. HIRShaUt,* P. Glade,* L. O. Vieira,* E. Ainbender,* L. Siltzbach,* and K. Hirschhorn, New York. (140)

25. Inhibition of Leukocytic Proteases in Purulent Sputum by Alpha ${ }_{1}$ Antitrypsin. J. Lieberman,* M. Монамed,* and C. Mittman,* Duarte, Calif. (introduced by E. Beutler). (187)

\title{
Joint Program with the American Federation for Clinical Research, Inc.
}

\author{
SUNDAY AFTERNOON, MAY 3
}

\section{CARDIOVASCULAR PHYSIOLOGY}

\author{
2:00 p.m., Carolina Room, Chalfonte \\ Co-Chairmen: Dr. Richard Gorlin \\ Dr. Henry D. McIntosh
}

1. Myocardial Function and Metabolism in Chronic Diabetes Mellitus. T. J. Regan, M. I. Khan,* M. U. Jesrani,* H. A. Oldewurtel,* and P. O. Ettinger,* Newark, N. J. ASCI (248)

2. Dissociation of Cardiac Inotropic and Membrane Effects of Ouabain. P. Dempsey,* K. Kent,* and T. CoOper, Bethesda, Md. AFCR

3. Saphenous and Colic Venomotor Responses to Prostaglandin $F_{2 a}$. A. L. MARK,* P. G. SCHMId,* J. W. Eckstein,** and M. G. Wendling,* Iowa City, Iowa. ASCI (194)

4. A Teratogenic Cause of Electrocardiographic Abnormalities. W. S. Harris, C. L. Barbee,* S. Pruzansky,* A. Stern,* C. V. Shah,* and A. Hastreiter,* Chicago, I11. AFCR

5. Nonuniform Contractility across the Heart Wall Caused by Redistribution of Coronary Flow. E. S. KIRK,* M. E. Turbow,* C. W. Urschel,* and E. H. Sonnenblick, Boston, Mass. ASCI (163)

6. Comparison of the Peripheral Vascular Effects of Glucagon, Norepinephrine, Isoproterenol, and Dopamine. G. Glick, Houston, Tex. AFCR

7. The Effect of Contrast Media Injection on Left Ventricular Function in Dogs. C. B. Mullins,* S. J. Leshin,* D. S. Mierzwiak,* and J. H. Mitchell, Dallas, Tex. (introduced by C. B. Chapman**). ASCI (219)
8. Left Ventricular Geometry and Sarcomere Structure in Acute and Chronic Cardiac Dilation. J. Ross, JR., E. H. Sonnenblick, R. Taylor,* H. M. Spotnitz,* and J. W. Covell,* Boston, Mass., and San Diego, Calif. ASCI (260)

9. Selective Right Coronary Artery Indicator-Dilution Curves in Normal and CAD Patients. A. J. LIEDTKe,* P. J. LaRaia, D. Borkenhagen,* H. G. Kemp, and R. Gorlin,** Boston, Mass. AFCR

10. Impaired Fibrinolysis in Patients with Type IV Hyperlipoproteinemia. D. R. Rosing,* P. Brakman,* D. R. Redwood,* and S. E. Epstein, Bethesda, Md., and Washington, D. C. AFCR

11. The Krypton ${ }^{85}$ Disappearance Rate as an Index of Capillary Blood Flow in Clubbed Fingers. S. Racoceanu,* N. Naftchi,* A. Suck,* and M. Mendlowitz,** New York. ASCI (245)

\section{DERMATOLOGY}

$$
\text { 2:00 p.m., West Room, Haddon Hall }
$$

$$
\begin{aligned}
\text { Co-Chairmen: Dr. Thomas B. Fitzpatrick } \\
\text { Dr. Joseph S. McGuire }
\end{aligned}
$$

1. Decreased Rate of Thymidine Incorporation into DNA of Some Xeroderma Pigmentosum Patients' Lymphocytes after Ultraviolet Irradiation In Vitro. P. G. BURK,* M. A. Lutzner, and J. H. Robbins,* Bethesda, Md. AFCR 
2. The Effect of Methotrexate on DNA Synthesis in Psoriasis. G. Weinstein, G. Goldfaden,* and P. Frost, Miami, Fla. AFCR

3. Hydroxyurea : a New Treatment for Psoriasis. J. W. YARBRo and U. LeAvell,* Lexington, Ky. AFCR

4. A Molecular Abnormality of Human Keratin. L. A. Goldsmith and H. P. Baden, Boston, Mass. AFCR

5. Studies on Chemistry of Elastin. D. P. VARAdI, Toronto, Canada (introduced by $\mathrm{R}$. Volpe). AFCR

6. A Method for Distinguishing the Breakdown Products of Skin Collagen from those of Bone Collagen in Man. S. Pinnell,* R. Fox,* and S. Krane, Boston, Mass. ASCI (237)

7. Studies on "Chalone" in Epidermal Proliferation. J. Marrs* and J. Voorhees, Ann Arbor, Mich. AFCR

8. Demonstration of Tyrosinase Activity in Melanosomes Contained within Keratinocytes. K. Toda,* J. Matsumoto,* and T. B. Fitzpatrick,** Boston, Mass. ASCI (308)

9. Paramyxovirus-Like Inclusions in Several Skin Diseases of Unknown Etiology. K. Hashimoto, Memphis, Tenn. AFCR

10. IgE in Atopic Dermatitis. M. Ogawa,* P. A. Berger,* O. R. McIntyre, W. E. Clendenning, H. Tomioka,* and K. IshizakA,* Hanover, N. H., and Denver, Colo. AFCR

11. Human Cutaneous Vascular Smooth Muscle Responses to Catecholamines, Histamine, Serotonin, Bradykinin, Angiotensin, and Prostaglandins. R. K. Winkelmann,* W. M. Sams, JR.,* and J. H. King, ${ }^{*}$ Rochester, Minn.' (introduced by W. S. Fowler**). ASCI (331)

\section{ENDOCRINOLOGY}

2:00 p.m., Pennsylvania Room III, Haddon Hall

Co-Chairmen: Dr. John T. Potts, Jr. Dr. Seymour Reichlin

1. The Rate of Extrathyroidal Conversion of Thyroxine to Triiodothyronine in Man. C. S. Pittman,* J. B. Chambers, JR.,* and V. H. Read,* Birmingham, Ala. (introduced by T. N. James). ASCI (238)

2. Nature of the Iodoproteins Formed after Injection of Labeled Thyroid Hormones. M. I. SuRKs* and J. H. OPPENHEIMER, Bronx, N. Y. ASCI (299)

3. Effect of Angiotensin on Adrenal and Pituitary Function in Man. S. Rayyis* and R. Horton, Los Angeles, Calif. AFCR

4. Secretion of 18-Hydroxydeoxycorticosterone in Human Hypertensive Disease. J. C. Melby, T. E. Wilson, ${ }^{*}$ and S. L. Dale,* Boston, Mass. ASCI (204)

5. A Cyclic Adenosine-3',5'-Monophosphate-Dependent Protein Kinase from the Adrenal Cortex: Comparison with a Cyclic Adenosine-3',5'-Monophosphate-Binding Protein. G. N. Gill* and L. D. Garren, La Jolla, Calif. ASCI (108)
6. Cyclic AMP Excretion in Hypercalcemic States. $\mathrm{H}$. Estep, M. Fratkin,* A. Moser,* and F. Robinson,* Richmond, Va. AFCR

7. Arginine Vasopressin: a Minority of Vasopressin Immunoreactivity in Plasma. G. L. Robertson,* L. A. KLeIn,* J. Roth, and P. Gorden,* Bethesda, Md. ASCI (252)

8. "Radio-Receptor Assay" of ACTH : a New Assay for Polypeptide Hormones. R. Lefkowitz,* J. Roth, and I. Pastan, Bethesda, Md. ASCI (180)

9. A Radioimmunoassay for Vasopressin Binding ProteinsNeurophysin. K. W. ChenG* and H. G. FrIESEN, Montreal, Canada. AFCR

10. Radioimmunoassay for Human Proinsulin C-Peptide. F. Melani,* P. Oyer,* S. Cho,* A. H. Rubenstein, and D. F. Steiner,* Chicago, Ill. AFCR

11. Measurement of Prolactin in Human Plasma by In Vitro Bioassay. D. L. Kleinberg and A. G. Frantz, New York. AFCR

\section{GASTROENTEROLOGY}

\author{
2:00 p.m., Windsor Room, Haddon Hall \\ Co-Chairmen: Dr. John S. Fordtran \\ Dr. Henry O. Wheeler
}

1. Ethanol-Induced Human Esophageal Motor Dysfunction. W. J. Hogan, S. R. V. de Andrade,* and D. H. WinSHIP, Milwaukee, Wis. AFCR

2. The Nature and Location of the Lower Esophageal Ring. J. L. Bauer,* R. K. Goyal, and H. M. Spiro,* New Haven, Conn. AFCR

3. The Role of the Pancreas in Vitamin $B_{12}$ Absorption. P. P. Toskes* and J. J. Derin, Philadelphia, Pa. AFCR

4. Intestinal Absorption of 5-Methyltetrahydrofolate (MTHF). W. B. Strum,* P. F. Nixon,* H. J. Binder, and J. R. Bertino, New Haven, Conn. AFCR

5. Inhibition by Diphenylhydantoin (Dilantin) of Folic Acid Absorption in Man. C. D. Gerson,* G. W. Hepner,* N. Brown,* N. Cohen,* V. Herbert, and H. D. JANowitz,** New York. ASCI (105)

6. Hepatic Ethanol Oxidation: Evidence against a Distinct Microsomal Ethanol Oxidizing System. E. A. CArTer* and K. J. Isselbacher, ${ }^{* *}$ Boston, Mass. AFCR

7. Hepatic Porphyria: Inappropriate Induction of Delta Aminolevulinic Acid Synthetase by Enhanced Hemoprotein Turnover. U. A. MeYer* and H. S. Marver, San Francisco, Calif. ASCI (209)

8. Phospholipid Regulation of Bile Salt-Stimulated Biliary Cholesterol Excretion. W. G. HARdison and J. T. Apter,** Chicago, Ill. AFCR

9. Essential Fatty Acids, Gallstones, and Phospholipid Metabolism. J. Balint, D. Beeler,* D. Treble,* and E. Kyriakides,* Albany, N. Y. ASCI (21) 
10. Hypo-Beta Lipoproteinemia in Childhood: Evidence for Two Types by Histological, Ultrastructural, and Immunological Analysis. J. C. Partin* and W. K. SchUBERT,* Cincinnati, Ohio (introduced by A. A. Weech**). ASCI (230)

11. Adenyl Cyclase Activity of Guinea Pig Gastric Mucosa : Stimulation by Histamine and Prostaglandins. C. V. Perrier* and L. Laster, Bethesda, Md. ASCI (232)

\section{GENETICS}

\section{2:00 p.m., Garden Room, Haddon Hall \\ Co-Chairmen: Dr. Leon E. Rosenberg Dr. J. Edwin Seegmiller}

1. The Effect of $\beta^{7 s \Delta s n}$ on Interactions of Sickling Hemoglobins. R. M. Bookchin,* R. L. NAgel, and H. M. RanNey,** New York. AFCR

2. Intermittent Ataxia with Pyruvate Decarboxylase Deciency. J. P. Blass, D. Lonsdale,* B. W. UhlendorF,* and J. Avigan,* Bethesda, Md., and Cleveland, Ohio AFCR

3. Mechanism of Fructose Diphosphate (FDP) Activation of a Mutant Pyruvate Kinase (PK) from Human RBC. G. F. Munro* and D. R. Miller, Rochester, N. Y. AFCR

4. Genetic Heterogeneity of the Mediterranean Glucose-6Phosphatase Deficiency. G. Stamatoyannopoulos,* V. Voigtlander,* P. Kotsakis,* and A. Akrivakis,* Seattle, Wash, and Athens, Greece (introduced by A. G. Motulsky**). ASCI (294)

5. Genetic Linkage between a Locus for 6-PGD and a Rhesus Locus. L. R. Weitkamp, S. A. Guttormsen,* and R. M. GReEndyKe,* Rochester, N. Y. AFCR

6. Polarized Light Microscopy of Saliva in Fabry's Disease. J. Hood, W. B. Bean,** W. J. Mergner,* and E. E. Pixley,* Iowa City, Iowa. AFCR

7. Ceramide Trihexosidosis with Renal Involvement but without Angiokeratoma : a Variance of Fabry's Disease? J. T. Clarke,* J. KnaAck,* J. C. Crawhall,* and and L. S. Wolfe,* Montreal, Canada (introduced by H. G. Friesen). AFCR

8. Heterogeneity of Genetic Variants in Hereditary Angioneurotic Edema. C. A. Alper, F. S. Rosen, J. Pensky,* M. R. Klemperer, * and V. H. Donaldson, Boston, Mass., Cincinnati and Cleveland, Ohio. ASCI (9)

9. Ectodermal Dysplastic Keratin: a Proposed Structure. R. J. M. GolD* and C. R. Scriver,* Montreal, Canada (introduced by C. H. Hollenberg). AFCR

10. Intestinal Transport of Iron in Mice with $\mathrm{X}$-Linked Anemia. J. A. Edwards* and R. M. Bannerman,** Buffalo, N. Y. AFCR

11. Hereditary Bilateral Acoustic Neuroma. D. F. Young,* J. McNew,* R. Eldridge, and W. J. Gardner,* Bethesda, Md., and Cleveland, Ohio. AFCR

\section{HEMATOLOGY}

\author{
2:00 p.m., Vernon Room, Haddon Hall \\ Co-Chairmen: Dr. Hymie L. Nossel \\ Dr. Robert I. Weed
}

1. Restoration of Red Cell 2,3-Diphosphoglycerate (DPG) in Stored Blood. F. A. Oski, S. F. Travis,* L. D. Miller,* and E. Cannon,* Philadelphia, Pa. AFCR

2. The Interaction of 2,3-Diphosphoglycerate with Certain Human Hemoglobins. H. F. BUNN* and R. W. BRIEHL, Bronx, N. Y., and Boston, Mass. ASCI (45)

3. In Vitro and In Vivo Modification of Human Macrophage Receptor for IgG Globulin. A. LoBuglio and J. Rinehart,* Columbus, Ohio. AFCR

4. Studies of Platelet and Fibrinogen Consumption. L. A. HARKER,* Seattle, Wash. (introduced by C. A. Finch**). ASCI (127)

5. The Effect of Fibrin-Stabilizing Factor on the Subunit Structure of Human Fibrin. P. A. McKeE,* P. MATTOCK,* and R. L. HILl,* Durham, N. C. (introduced by M. P. Tyor**). ASCI (203)

6. A Specific Assay for the Detection of Intravascular Coagulation. C. T. KISKER* and R. RUSH,* Cincinnati, Ohio (introduced by E. L. Pratt**). ASCI (164)

7. The Immunologic Differentiation of the Antihemophilic Factor (Factor VIII) Abnormalities in Classic Hemophilia and Von Willebrand's Disease. T. S. Zimmerman,* O. D. Ratnoff,** and A. E. Powell,* Cleveland, Ohio. ASCI (339)

8. De Novo Biosynthesis of Glutathione in Extracts from Human Erythrocytes. P. W. Majerus, V. Minnich,* and D. MoHLER,* St. Louis, Mo., and Charlottesville, Va. ASCI (191)

9. Inducible Heme Oxygenase in the Kidney: a Model for the Homeostatic Control of Hemoglobin Catabolism. N. R. Pimstone,* P. Engel,* P. T. Seitz,* H. S. Marver, and R. Schmid,** San Francisco, Calif. ASCI (235)

10. The Pathogenesis of Burr Cells in Uremia. R. A. Cooper,* Boston, Mass. (introduced by J. H. Jandl). ASCI (69)

11. Positive Direct Antiglobulin Reactions with Antilight Chain Antisera in Patients with "Coombs Negative" Hemolytic Anemia. M. R. MacKenzIE, Cincinnati, Ohio. AFCR

\section{IMMUNOLOGY AND CONNECTIVE TISSUE}

$$
\begin{aligned}
& \text { 2:00 p.m., Rutland Room, Haddon Hall } \\
& \text { Co-Chairmen: Dr. Edward C. Franklin } \\
& \text { Dr. Halsted R. Holman }
\end{aligned}
$$

1. An Inactivator of Anaphylatoxin in Normal Human Serum. V. A. BoKISCH* and H. J. Müller-Eberhard, La Jolla, Calif. ASCI (33) 
2. Colony Inhibition of Fibroblasts from Chimeric Dogs Mediated by the Dogs' Own Lymphocytes and Specifically Abrogated by Their Serum. I. Hellström,* K. E. Hellström,* R. Storb,* and E. D. Thomas,** Seattle, Wash. ASCI (134)

3. Heterogeneity in Assembly of Human Macroglobulins. J. Buxbaum,* S. Zolla,* M. D. Scharff, and E. C. Franklin, New York. ASCI (48)

4. Changes in Cell Response and Antibody Concentration after Immunotherapy for Pollen Allergy. D. A. LEvy and L. M. Lichtenstein, Baltimore, Md. AFCR

5. In Vitro Lymphocyte Transformation: the Restoration of Purified Lymphocyte Responses by Allogeneic Macrophages from Normal and Anergic Patients. R. M. Blaese, J. J. Oppenheim, R. Seeger,* and T. A. Waldmann, Bethesda, Md. AFCR

6. Two Kinds of Genetic Control of Reagin Production in the Mouse. B. B. Levine and N. M. VAZ,* New York. ASCI (184)

7. Induction of "Delayed Hypersensitivity" in a Wiscott Aldrich Patient by Transfer Factor. A. S. Levin,* D. P. Stites,* L. E. Spitler,* M. A. Sahud,* and H. H. Fudenberg, San Francisco, Calif. AFCR

8. Variable Representation and Immunogenicity of Histocompatibility Antigens on Different Tissues. A. Hotri,* S.-M. Fu,* and H. Holman, Stanford, Calif. ASCI (146)

9. The Increased Reactivity of Human Lymphocytes to Streptococcal Antigens in Chronic Glomerulonephritis. R. E. FAlK and J. ZABriskie,* Toronto, Canada, and New York. AFCR

10. Differences in Carbohydrate Content between Myeloma and Normal Immunoglobulin Light Chains. H. C. Sox,* Bethesda, Md. (introduced by J. L. Fahey). ASCI (291)

11. Serum and Secreted IgE Globulin in Man. S. E. SALMoN, San Francisco, Calif. AFCR

\section{INFECTIOUS DISEASES}

\section{2:00 p.m., Viking Room, Haddon Hall \\ Co-Chairmen: Dr. Robert G. Petersdorf Dr. Jay P. Sanford}

1. Bacteremia in the Pathogenesis of Ascending Pyelonephritis in the Rat. J. FIERER* and A. I. BRAUdE,** San Diego, Calif. ASCI (92)

2. Probable Transmission of Rubella Vaccine Virus Strain. G. M. Schiff, C. Weinl,* L. Altschuler,* T. Rotte,* and J. BRINKer,* Cincinnati, Ohio. AFCR

3. Identification of an Epidemiologically Virulent Strain of Group C Meningococcus. H. Beaty* and G. Counts,* Seattle, Wash. (introduced by R. G. Petersdorf). ASCI (26)

4. Suppression of Interferon Response in Uremic Lymphocytes. C. V. SAnders, JR.,* J. P. LUBY, and J. P. SANFord,** Dallas, Tex. AFCR
5. Impairment and Recovery of Pulmonary Antibacterial Defense Mechanisms after Oxygen Administration. G. Huber,* M. La Force,* and R. Mason,* Boston, Mass., and Bethesda, Md. (introduced by E. H. Kass**). ASCI (149)

6. The Role of Polyribophosphate in Immunity to Hemophilus influenzae b. D. H. Smith,* P. Anderson,* R. B. Johnston, Jr.,* A. I. Berkel,* and J. Pitr,* Boston, Mass. (introduced by C. A. Janeway**). ASCI (288)

7. Shigella Enterotoxin: Isolation and Characterization. G. T. Keusch, L. J. Mata,* and G. F. Grady, Boston, Mass., and Guatemala City, Guatemala. AFCR

8. Long-Term (10-15 year) Follow-Up of Bacteriuria of Pregnancy. S. H. Zinner and E. H. KAss,** Boston, Mass. AFCR

9. The Killing of L-Phase Variants in Normal Human Serum: a Complement Dependent Antibody System. Z. A. McGee, H. B. Ratner,* R. E. Bryant, A. S. Rosenthal, and N. G. Koenig, Nashville, Tenn., and Bethesda, Md. AFCR

10. Granulocyte Chemotaxis in Chediak-Higashi Syndrome (CHS). R. Clark* and H. Kimball, Bethesda, Md. AFCR

11. Complete Deficiency of Leukocyte Glucose-6-Phosphate Dehydrogenase with Defective Bactericidal Activity. M. R. Cooper,* L. R. Dechatelet,* M. F. Lavia,* C. E. McCall, C. L. Spurr,* and R. L. Baehner,* Winston-Salem, N. C., and Boston, Mass. (introduced by M. Meads**). ASCI (68)

\section{KIDNEY AND ELECTROLYTE}

\section{2:00 p.m., Pennsylvania Room II, Haddon Hall \\ Co-Chairmen: Dr. Howard S. Frazier Dr. Richard M. Hays}

1. A Gamma Aminobutyricacid "Shunt" in Kidney: Role in Acidosis. D. T. Whelan,* C. R. Scriver, and F. МонуUdDin,* Montreal, Canada. ASCI (325)

2. Effect of Saline Infusion on Filtration Rate and Sodium Reabsorption in Single Superficial and Juxtamedullary Nephrons. R. L. Jamrson,* St. Louis, Mo. (introduced by S. Wessler**). ASCI (154)

3. Effect of Extracellular Volume Expansion (VE) on Filtrate Distribution in the Dog. H. Mandin,* A. H. Israelit,* F. C. Rector, JR., and D. W. Seldin,** Dallas, Tex. AFCR

4. Independent Effects of Salt Depletion and Oncotic Pressure in the Proximal Tubule. E. J. Weinman,* J. P. Hayslett,* M. Weiner,* M. Kashgarian,* and F. H. Epstein, New Haven, Conn. ASCI (323)

5. Sodium Chloride and Water Transport in the Descending Limb of Henle. J. P. Kokko,* Dallas, Tex. (introduced by F. C. Rector, Jr.). ASCI (168)

6. Effects of Adrenalectomy and Hormone Replacement on the Na-K-ATPase and Other Plasma Membrane Enzymes in Renal Tissue. E. Hendler, J. Torretri,* L. Kupor,* and F. H. Epstein,** New Haven, Conn. AFCR 
7. Depression of Proximal Tubular Sodium Reabsorption by Beta Adrenergic Stimulation. J. R. GILL, JR., and A. G. T. CAsper,* Bethesda, Md. (introduced by J. H. Baxter**). ASCI (109)

8. Simultaneous Measurement of Intracellular $\mathrm{pH}$ with a Weak Acid and a Weak Base. S. Adler, Pittsburgh, Pa. AFCR

9. Micropuncture Study of the Relative Importance of Altered Blood Composition in the Depression of Proximal Reabsorption during Volume Expansion. W. CIRKSENA, N. Lawson,* J. McNeIL,* and R. Schrier, Washington, D. C. AFCR

10. Pathogenesis of Hyperparathyroidism in Chronic Renal Disease. E. Slatopolsky,* S. Caglar,* J. P. Pennell,* D. Taggart,* J. M. Canterbury,* E. Reiss, and N. S. Bricker, St. Louis, Mo., and Chicago, Ill. ASCI (285)

11. Complement Component Levels in Renal Diseases. E. J. Lewis,* C. B. Carpenter, and P. H. Schur, Boston, Mass. AFCR

\section{METABOLISM}

\section{2:00 p.m., Pennsylvania Room I, Haddon Hall \\ Co-Chairmen: Dr. George F. Cahill Dr. David M. Kipnis}

1. Plasma Triglyceride and Lipoprotein Lipase Activity in Mammary Gland and Adipose Tissue During Pregnancy and Lactation. M. Hamosh,* T. R. Clary,* S. S. Chernick,* and R. O. Scow,* Bethesda, Md. (introduced by L. Recant). AFCR

2. Studies on the Inherited Protein Defect in Abetalipoproteinemia: the Occurrence of Very Low Density Lipoproteins. A. M. Gotro,* R. I. Levy,* K. JoH N,* and D. S. Fredrickson, Bethesda, Md. (introduced by $\mathrm{T}$. Cooper). ASCI (118)

3. A Free Apolipoprotein in Human Plasma. D. E. WILson and R. S. LeEs, Cambridge, Mass. AFCR

4. The Measurement of Cyclic Nucleotides by Radioimmunoassay. A. L. Steiner,* C. W. Parker, and D. M. KIPNIs, St. Louis, Mo. ASCI (296)

5. Solubilization of Myocardial Adenyl Cyclase with Loss of Hormone Responsiveness. G. S. Levey,* Bethesda, Md. (introduced by G. D. Aurbach). ASCI (183)

6. On the Physiological Mechanism of Sensory Changes Produced with LSD-25. R. Henkin, Bethesda, Md. ASCI (135)

7. Inhibition of the Neuromuscular Junction by Porphobilinogen and Porphobilin as Compared with Uroporphyrins I and III. D. S. Feldman,* R. D. Levere,* J. S. Lieberman,* R. A. Cardinal,* and C. J. Watson,** Brooklyn, N. Y., and Minneapolis, Minn. ASCI (89)

8. Glucagon: Levels and Metabolic Effects in Man under Prolonged Fasting. E. B. Marliss,* T. T. AokI,* and G. F. CAHILl, JR., Boston, Mass. ASCI (195)
9. Essential Role of Phosphoribosylpyrophosphate in Regulation of Purine Biosynthesis in Cultured Human Fibroblasts. W. N. Kelley, I. H. Fox,* and J. B. WyngaARden, ** Durham, N. C. AFCR

10. Therapeutic Effects of L-Carnitine in Experimental Intoxication with Diphtheria Toxin. D. R. Challoner,* W. C. Elliott,* and I. Mandelbaum,* Indianapolis, Ind. (introduced by J. B. Hickam**). ASCI (56)

11. Postnatal Muscle Fiber Assembly: Autoradiographic Localization of Newly Synthesized Myofibrillar Proteins. E. Morkin, Boston, Mass. AFCR

\section{NEOPLASIA}

\section{2:00 p.m., Solarium, Haddon Hall \\ Co-Chairmen: Dr. Paul Calabresi Dr. David P. Rall}

1. Burkitt's Tumor: a Comparative Study of the Disease in the United States and Africa. P. P. Carbone,* J. L. ZIEgler,* C. H. Brown,* R. Morrow,* and C. Berard,* Bethesda, Md., and Kampala, Uganda (introduced by C. G. Zubrod**). ASCI (52)

2. The SJL/J Mouse: a New Murine Model for Studying Amyloidosis in Plasma-Cell Disorders. R. S. HILL* and R. F. BAKEmeier, Rochester, N. Y. AFCR

3. Autologous and Allogeneic Bone Marrow Grafts in Monkeys following Cyclophosphamide (CY). R. STORB,* C. D. Buckner,* L. A. Dillingham,* and E. D. Thоmas,** Seattle, Wash. AFCR

4. Synchronization and Recruitment in Acute Leukemia. B. Lampkin,* T. Nagao,* A. Lichtenberg,* and A. Mauer, Cincinnati, Ohio. ASCI (175)

5. Transfer RNA Methylase Alterations in Polyoma and Spontaneous Malignantly Transformed Mouse Cells in Culture. S. E. WRIGHT,* R. C. Y. Ting,* and R. C. GALLo, Bethesda, Md. AFCR

6. The Requirement of Contact in Cell-Mediated Specific Immunity to Tumor Cells. F. J. Cummings* and P. Calabresi, Providence, R. I. AFCR

7. Hematological Metabolism of Daunomycin in Man. D. H. Huffman,* N. R. Bachur,* and M. GeE,* Baltimore, Md. (introduced by J. Block). AFCR

8. Characterization of a Folic Acid-Binding Factor in Leukemic Cells. S. P. RothenberG* and M. DACosta,* New York (introduced by S. Ulick**). ASCI (262)

9. Peripheral Characteristics of Leukocytes in Monocytic Leukemia: Possible Relationship to Clinical Manifestations. M. A. Lichtman and R. I. WeEd,** Rochester, N. Y. AFCR

10. L-Asparaginase (ASP) Effect on Mouse Bone Marrow Grown In Vitro. C. Brown,* G. Canellos, and P. P. Carbone, Bethesda, Md. AFCR

11. Breast Cancer as an Estrogen Target: the Incidence and Concentration of Specific Binding Sites for $17 \beta$-Estradiol. S. G. Korenman, Torrance, Calif. AFCR 


\section{PULMONARY}

\author{
2:00 p.m., Music Room, Chalfonte \\ Co-Chairmen: Dr. Stuart Bondurant \\ Dr. John F. Murray
}

1. Pulmonary Iron and Ferritin Transport. J. S. Adamson* and E. D. Robin, ${ }^{* *}$ Pittsburgh, Pa. ASCI (2)

2. Alveolar Macrophage Transport in the Early PostExposure Period-a New Pathway? G. M. Green, Burlington, Vt. AFCR

3. Human Alveolar Macrophages: Comparison of Phagocytic Ability, Glucose Utilization and Ultrastructure in Smokers and Nonsmokers. J. O. HARRIs,* E. W. Swenson, ${ }^{* *}$ and J. E. Joh nson, ${ }^{* *}$ Gainesville, Fla. AFCR

4. Human Alveolar Macrophages: Functional Differences between Smokers and Nonsmokers. A. B. CoHEN* and M. J. Cline, San Francisco, Calif. AFCR

5. ${ }^{18} \mathrm{O}_{2}$ Diffusing Capacity at Rest and during Exercise in Normal Man. H. Gong,* D. Meyer,* R. Hyde, J. GiL- lespie,* and C. Cross, Davis, Calif., and Rochester, N. Y. AFCR

6. The In Vivo Response of Pulmonary Tissue Water to Osmotic Transients. R. M. Efrros, ${ }^{*}$ W. Perl,* J. ARBort,* and F. P. Chinard,** Newark, N. J. ASCI (83)

7. Composite and Regional Washout of ${ }^{183}$ Xenon Gas from the Lungs: Comparison with Nitrogen Washout. M. Guisan,* G. M. Tisi, W. L. Ashburn,* and K. M. Moser, La Jolla, Calif. AFCR

8. Action and Metabolism of Bradykinin in Isolated Lungs. B. Levine,* R. Talamo,* D. Strieder, and H. Kazemi, Boston, Mass. AFCR

9. Acute Buffering of Carbon Dioxide by Tissues In Vivo. N. S. Cherniack,* N. H. Edelman,* P. G. Tuteur,* and T. J. Trueb,* Philadelphia, Pa. (introduced by A. P. Fishman**). ASCI (57)

10. Measurement of Diaphragmatic Blood Flow and Oxygen Consumption in the Dog. D. F. Rochester,* New York (introduced by R. M. Harvey**). ASCI (255)

11. Acute and Chronic Effects of Immunosuppressive Agents on Intrapulmonary Defense Mechanisms. G. L. HuBER,* F. M. LaForce,* R. J. Mason,* and A. P. Monaco,* Boston, Mass., and Bethesda, Md. (introduced by E. H. Kass**). AFCR 


\title{
American Federation For Clinical Research, Inc.
}

\author{
27TH ANNUAL MEETING
}

SUNDAY MORNING, MAY 3

GENERAL MEETING

8:30 a.m., Pennsylvania Room, Haddon Hall, Dr. Eugene Braunwald, Presiding

$$
\text { BUSINESS SESSION }
$$

\section{SCIENTIFIC SESSION}

(The presentation of each paper will be limited to 12 min.)

1. Sites of Pulmonary Vasomotor Reactivity during Alveolar Hypoxia and Serotonin and Histamine Infusion. J. B. Glazier and J. F. Murray,** San Francisco, Calif.

2. New Evidence for Bone Marrow Stem Cell Origin of the Pulmonary Alveolar Macrophage. Mary ANn Brunstetter,* Jeanne M. Hardie,* Robert Shiff,* Jerry P. Lewis, and Carroll E. Cross, Davis, Calif.

3. Serum Amylase Removal. William C. Duane,* Roger Frerichs,* and Michael D. Levitt,* Minneapolis, Minn. (introduced by J. B. Carey, Jr.).

4. Phenobarbital Enzyme Induction and Bile Section in Intrahepatic Cholestasis. H. L. ShARP and B. L. MIRkıN, Minneapolis, Minn.

\section{PRESIDENTIAL ADDRESS}

5. A Humoral Sodium Transport Inhibitor during Chronic Volume Expansion in Dogs. V. M. Buckalew, JR., and C. D. Lancaster, ${ }^{*}$ Atlanta, Ga.

\section{INTERMISSION}

SCIENTIFIC SESSION

(concluded)

6. Influence of Fat Cell Size and Dietary Carbohydrate Intake on Adipose Tissue Insulin Sensitivity in Adult Onset Obesity. L. Salans, E. Horton, and E. Sims, Hanover, N. H., and Burlington, Vt.

7. Ectopic Production of Human Chorionic Somatomammotropin in Patients with Cancer. Bruce D. Weintraub and Saul W. Rosen, ${ }^{* *}$ Bethesda, Md.

8. Prediction of Leukocyte Transfusion Response by Leukoagglutinin and Lymphocytotoxicity Testing. IRA GoLDstein,* Harmon Eyre,* Edward Henderson, Paul Terasaki,* and Robert Graw, Jr.,* Bethesda, Md., and Los Angeles, Calif.

9. Decreased Synthesis of the Third Component of Complements in Hypocomplementemic Systemic Lupus. A. J. Sliwinski and N. J. ZvaIfler, ** Washington, D. C.

10. Effects of Catecholamines and Adrenergic Blocking Agents on Cyclic Nucleotides in Human Plasma. J. H. Ball,* N. I. Kaminsky,* A. E. Broadus,* J. G. Hardman,* E. W. Sutherland,* and G. W. Liddle,** Nashville, Tenn.

\section{AMERICAN FEDERATION FOR CLINICAL RESEARCH A N D THE SOCIETY FOR PEDIATRIC RESEARCH JOINT SPONSORSHIP OF TWO SYMPOSIA}

\section{SYMPOSIUM I RECENT ADVANCES IN PULMONARY VASCULAR PHYSIOLOGY}

Saturday, May 2, 4:00 p.m., Pennsylvania Room II, Haddon Hall, Dr. Abraham M. Rudolph, Presiding

1. The Distribution of Blood Flow in the Lung. JонN West, La Jolla, Calif.

2. The Nervous Regulation of the Pulmonary Circulation. Alfred Fishman, Philadelphia, 'Pa.

3. Hypoxic Response of Pulmonary Circulation. Thomas Lloyd, Cleveland, Ohio.

\section{SYMPOSIUM II CELLULAR ENGINEERING}

Saturday, May 2, 4:30 p.m., Traymore Room, Traymore Hotel, Dr. Robert A. Good, Presiding

1. Introduction to Cellular Engineering. Problems and Potentials. The Obstacle of Graft-Versus-Host Reaction. RoBert A. Good, Minneapolis, Minn.

2. Successful Marrow Transplantation for Correction of Immune Deficiency. Rich ARD A. GATtI, Minneapolis, Minn.

3. Matching and Typing and Albumin Gradient for Transplantation of Marrow in Minnesota and Holland. HILaIre Meuwissen, Minneapolis, Minn. 


\title{
A MERICAN FEDERATION FOR CLIN ICAL R EjSjEARCH S Y M P O I U M
}

\section{EXPERIMENTS IN THE DELIVERY OF HEALTH CARE AND THEIR IMPORTANCE IN , i! MEDICAL SCHOOLS}

\author{
Dr. David E. Rogers, Chairman \\ Participants : \\ 1. Dr. E. Harvey Estes, Jr., Durham, N. C. \\ 2. Dr. Sidney S. Lee, Boston, Mass. \\ 3. Dr. Charles E. Lewis, Boston, Mass. \\ 4. Dr. Franklin Williams, Rochester, N. Y. \\ 5. Dr. Robert M. Hyssel, Baltimore, Md.
}

Saturday, May 2, 7:30 p.m., Pennsylvania Room II, Haddon Hall

\section{SA T URDAY EVEN ING, MAY 2}

\section{SUBSPECIALT Y M EET INGS}

(The presentation of each paper will be limited to $10 \mathrm{~min}$. )

\section{CARDIOVASCULAR I}

\section{7:30 p.m., Pennsylvania Room I, Haddon Hall \\ Dr. Edmund H. Sonnenblick, Presiding}

1. Alterations in the Circulatory Response to Exercise Following a Meal and Their Relationship to Postprandial Angina Pectoris. R. E. Goldstein, D. R. Redwood,* D. R. Rosing,* G. D. Beiser, and S. E. Epstein, Bethesda, Md.

2. Hemodynamic and Metabolic Stress Testing in Angina Pectoris. H. D. Dear, W. B. Jones, ** M. A. Harman,* and T. J. Reeves,** Birmingham, Ala.

3. Effects of Nitroglycerin on Regional Myocardial Blood Flow in Coronary Artery Disease. L. D. HoRwitz, R. Gorlin, W. J. Taylor,* and H. G. Kemp, Boston, Mass.

4. A Method of Measuring Blood Flow, Tissue Volume, and Metabolism in the Left Coronary Arterial System of Intact Man. G. A. Klassen, J. Agarwal,* P. Tanser,* S. Woodhouse,* and D. Marpole,* Montreal, Canada.

5. Responses of Coronary Vessels to Adrenergic Stimuli. D. R. McRaven,* F. M. Abboud, A. L. Mark, and H. E. MAYER,* Iowa City, Iowa.

6. Differential Reflex Adjustments in Cutaneous and Muscle Vascular Beds during Coronary Occlusion. H. G. Hanley,* J. C. Costin,* and N. S. Skinner, Jr., Atlanta, Ga.

7. Effects of Glucagon on Adenyl Cyclase Activity in the Left and Right Ventricles and Liver in Experimentally Produced Isolated Right Ventricular Failure. G. S. Levey, K. H. Prindle,* and S. E. Epstein, Bethesda, Md.
8. N-Ethyl Maleimide-Induced Inotropism. A. H. L. From,* Minneapolis, Minn. (introduced by Y. Wang**).

\section{CARDIOVASCULAR II}

7:30 p.m., Pennsylvania Room III, Haddon Hall

Dr. Edgar Haber, Presiding

1. Comparison of the Turnover Rates of Myosins from Cardiac, Red and White Skeletal Muscles. S. Kimata* and E. Morkin, Boston, Mass.

2. A Biochemical Defect of Sarcoplasmic Reticulum in a Hereditary Cardiomyopathy. E. Gertz,* A. Stam,* E. Bajusz,* and E. Sonnenblick, Boston, Mass.

3. Serum Digoxin Levels in Toxic and Nontoxic Patients by Enzymatic Isotope Displacement. GARY Brooker and Roger W. Jelliffe, Los Angeles, Calif.

4. Pulmonary Vascular Responses in Endotoxin Shock. Joseph Lindsay and Joseph W. Gilbert,* Atlanta, Ga.

5. Right and Left Heart Pressures in the Acutely Ill $\mathrm{Pa}$ tient. J. Forrester,* G. Diamond,* V. Ganz,* R. Dan2IG,* and H. J. C. Swan,** Los Angeles, Calif.

6. Hemodynamic Response to Intense Upright Exercise following Surgical Correction of Atrial Septal Defects or Tetralogy of Fallot. G. D. Beiser, R. E. Goldstein, D. R. Rosing,* D. R. Redwood,* A. G. Morrow, and S. E. Epstein, Bethesda, Md.

7. Hemodynamic Effects of Acute Diuresis in Man. D. H. Kramer,* J. P. Fernandez,* D. W. Vaules,* and B. F. SCHREINER,** Rochester, N. Y.

8. Accuracy of the Electrocardiogram in Detecting Operable Mitral Stenosis. Abe Walston,* Yihong Kong, Robert Peter,* Victor Behar,* and James Morris, Jr., Durham, N. C. 


\section{CLINICAL PHARMACOLOGY}

\section{7:30 p.m., Garden Room, Haddon Hall \\ Dr. John A. Oates, Presiding}

1. Intravenous Diazoxide in Hypertension. J. RICHARD Crout, F. V. V. Andreasen,* Robert I. Parks,* and David M. Heimbach,* Dallas, Tex.

2. Reduction of Arterial Pressure by the Amphetamine Metabolite, p-Hydroxynorephedrine. R. E. RANGNo,* J. S. Kaufmann,* J. H. Cavanaugh,* J. A. Oates, Nashville, Tenn.

3. Interactions between Digitoxin and Other Drugs In Vitro and In Vivo. Harvey M. Solomon, William B. Abrams,** and Steven D. Reich,* Newark, N. J.

4. Magnesium Sulfate in Digitalis Toxicity. RoBert $H$. Seller, Martin Neff,* Saul Mendelssohn,* Kwan E. Kim, and Charles Swartz, Philadelphia, Pa.

5. Quinidine for Arrhythmia Prophylaxis after Acute Myocardial Infarction. S. S. Bloomfield,** D. W. RomHilt,* T. C. ChOU,* and N. O. Fowler, ** Cincinnati, Ohio.

6. The Selective Changes in Regional Blood Flow Produced by Morphine. R. L. Miller,* R. Forsyth,* C. McCord,* and K. L. Melmon, San Francisco, Calif.

7. Displacement from Albumin and Potentiation of Warfarin by Five Acidic Drugs. Edward M. Sellers, Jan KoCH-WeSER, * Boston, Mass.

8. Inhibition of Meprobamate and Pentobarbital Metabolism by Ethanol. P. S. Misra,* H. GaNG,* E. Rubin,* and C. S. Lieber, New York.

\section{ENDOCRINOLOGY}

\section{7:30 p.m., Carolina Room, Chalfonte \\ Dr. Jesse Roth, Presiding}

1. Defective Testosterone Synthesis in the Male Pseudohermaphrodite Rat. R. Sherins, G. Schneider,* L. Bullock,* T. Vanha-Perttula,* V. Gay,* R. MidgLEY,* and C. W. BARdin, Bethesda, Md., and Ann Arbor, Mich.

2. Immunologic and Biologic Activity of Chorionic Gonadotropin Synthesized by Cloned Choriocarcinoma Cells in Tissue Culture. W. E. Brmson,* G. T. Ross,* and P. O. Kohler, Bethesda, Md.

3. Release of LH in Selected Men and Women after Administration of Hypothalamic LH-Releasing Hormone. A. J. Kastin, A. V. Schally,* C. Gual,* A. R. Midgley,* C. Y. Bowers,** A. CabezA,* and F. Flores,* New Orleans, La., Mexico City, Mex., and Ann Arbor, Mich.

4. Control of Gonadotropins in the Prepubertal Rat. R. S. Swerdloff, P. C. Walsh,* H. S. Jacobs,* W. D. Odell, Torrance, Calif.

5. Estrogen-Mediated Tissue Differentiation: Messenger RNA Translation. A. R. Means* and B. W. O'MALLEY, Nashville, Tenn.
6. Adrenocorticotropin Synthesis and Release in Rat Pituitary Monolayer Culture: the Effect of Glucocorticoids. N. Fleischer and W. Rawls,* Houston, Tex.

7. Serum Triiodothyronine Concentration in Various Thyroid Diseases. D. Bellabarba and P. SÉguin,* Sherbrooke, Quebec, Canada.

8. A Study of Thyroidal Sulfenyl Iodide. D. M. FAwCETt,* Edmonton, Canada (introduced by R. S. Fraser).

\section{GASTROENTEROLOGY}

\author{
7:30 p.m., Windsor Room, Haddon Hall \\ Dr. Graham H. Jeffries, Presiding
}

1. Evidence for a Non-Bile Salt Dependent Fraction of Canalicular Bile Flow. James L. Boyer and Gerald Klatskin,** New Haven, Conn.

2. Drug Metabolizing Enzymes in Viral Hepatitis. J. Doshi,* A. V. Opper,* and C. M. Leevy,** Newark, N. J., and East Orange, N. J.

3. $\Delta$-Aminolevulinate Synthetase and the Drug-Induced Increase in Microsomal Cytochrome P-450 of the Liver. Chull S. Song, Winnie Lee,* and Attallah Kappas, Bethesda, Md., and New York.

4. Ethanol and Steroid Metabolism. W. H. Admirand,* J. Cronholm,* J. Sjovall,* Stockholm, Sweden, and San Francisco, Calif. (introduced by Rudi Schmid).

5. Circulation Times in the Splanchnic and Hepatic Beds in Alcoholic Liver Disease. B. KotelanskI, $R$. J. Groszmann, I. M. Khatri, and J. N. Cohn, Washington, D. C.

6. The Differential Lead-a New Adjunct to Esophageal Manometry. Michael Antonelle and George B. Jerzy GLass,** New York.

7. Ionic Fluxes across Canine Antral Mucosa: Effects of Pentagastrin and Histamine. J. Rudick, M. L. CHAPMAN,* J. L. Werther,** and H. D. JANOwitz,** New York.

8. Effect and Site of Action of Diphenylhydantoin on Gastrointestinal Smooth Muscle. B. VANAsIn,* D. D. BAss,* A. I. Mendeloff,** and M. M. Schuster, Baltimore, Md.

\section{HEMATOLOGY}

$$
\begin{gathered}
\text { 7:00 p.m., Vernon Room, Haddon Hall } \\
\text { Dr. Stanley Yachnin, Presiding }
\end{gathered}
$$

1. Biochemical Variants of High $\mathrm{A}_{2}$-Beta Thalassemia. $\mathrm{T}$. F. Necheles and Uma S. RaI,* Boston, Mass.

2. Altered Regulation of Deoxyribonucleotide Synthesis in $B_{12}$ or Folate Deficiency. R. Silber, S. FujiokA,* C. F. Moldow, and R. Cox, New York.

3. Decreased 2,3-Diphosphoglycerate and Reduced Oxygen Consumption in Septic Shock. Harvey Sugerman,* Leonard D. Miller,* Frank A. Oski, Joseph Diaco,* Maria Delivoria-Papadopoulos, ${ }^{*}$ and Douglas Davidson,* Philadelphia, $\mathrm{Pa}$. 
4. Increased Synthesis of Hemoglobin Gun Hill Relative to Hemoglobin A. Ronald F. Rieder, Brooklyn, N. Y.

5. Storage of Erythrocytes in Artificial Media. LEE WoOD* and ERnest Beutler,** Duarte, Calif.

6. Studies of Cyclic Neutropenia in Grey Collie Dogs. David C. Dale,* Harry R. Kimball, and Sheldon M. WolfF, Bethesda, Md.

7. Cellular Studies on $\mu$ Chain Disease. D. ZuCKer-Franklin, E. C. Franklin, and L. Hamilton,* New York.

8. Laparotomy and Splenectomy in the Staging of Hodgkin's Disease. L. W. Allen* and J. E. Ultmann,* Chicago, Ill.

\section{NATIONAL BLOOD CLUB}

9:00 p.m., Vernon Room, Haddon Hall

Oxygen Affinity and Oxygen Transport

Participants :

1. Reinhold Benesch, New York.

2. Samuel Charache, Baltimore, Md.

3. Clement A. Finch, Seattle, Wash.

\section{INFECTIOUS DISEASES}

\section{7:30 p.m., Rutland Room, Haddon Hall \\ M. Glenn Koenig, Presiding}

1. Immune Response to Administration of a Polyvalent Pseudomonas Vaccine and Naturally-Acquired Pseudomonas Infection. Lowell S. Young,* Mahroo Haghbin,* and Donald Armstrong, New York.

2. Contrasting Epidemiology of Acute Rheumatic Fever and Acute Glomerulonephritis: Nature of the Antecedent Streptococcal Infection. A. L. Bisno, I. A. Pearce,* H. P. Wall,* and G. H. Stollerman,** Memphis, Tenn.

3. Serum Factors Essential for Intracellular Killing of Staphylococci. Donald H. Humphreys,* R. Russell MARTIN, and ARThUR White,** Indianapolis, Ind.

4. Sero-Epidemiologic Studies of Asymptomatic Meningococcal Infection. Theodore C. Eickhoff, Denver, Colo.

5. The Antibacterial Effect of Normal and Infected Urinary Bladder. W. L. Hand,* J. W. Sмith, and J. P. SanFord, ** Dallas, Tex.

6. Defective Candidacidal Activity of Leukocytes from Patients with Systemic Candidiasis. Robert I. Lehrer, San Francisco, Calif.

7. Hyporesponsiveness of Lymphocytes to PHA Stimulation In Vitro; Studies in Viral Hepatitis. S. S. Agarwal,* Baruch S. Blumberg,** Betty Jane S. Gerstley,* Alton I. Sutnick,** W. Thomas London,* and LawRENCE A. Loeb,* Philadelphia, Pa.

8. Seroconversion in a Susceptible Family Contact of Rubella Vaccinees. L. B. Lefkowitz, JR., R. R. Rafajko,* C. F. Federspiel,* and R. W. Quinn,* Nashville, Tenn., and Rockville, Md.

\section{METABOLISM}

7:30 p.m., Music Room, Chalfonte

Dr. DeWitt S. Goodman, Presiding

1. A Radioimmunoassay for Folic Acid in Serum and Whole Blood. M. DACosta* and S. P. Rothenberg, New York.

2. A Defect in the Oxidation of Citric Acid in a Patient with Congenital Lactic Acidosis. J. P. Blass, J. D. Schulman,* and D. S. Young,* Bethesda, Md.

3. The Organic Aciduria of Hereditary Fructose Intolerance. H. E. Williams, G. Johnson,* K. M. Wilson,* and, R. C. Morris, San Francisco, Calif.

4. Insulin Secretory Response to IV Glucose and Its Inhibition by Diazoxide in Prediabetes. M. R. SAntis, ${ }^{*} T$. Pozefsky, and J. S. Soeldner, Boston, Mass.

5. Chlorpropamide Hyponatremia: An Inappropriate $\mathrm{ADH}$ Syndrome. P. N. Weissman* and R. I. Gregerman, Baltimore, Md.

6. Insulin Resistance in Genetically Obese Hyperglycemic Mice. S. Genuth, Cleveland, Ohio.

7. Immunologic and Biologic Properties of Beef and Pork Insulin, Proinsulin, and Connecting Peptides. A. E. Kitabchi, S. S. Solomon, M. Palazzolo,* and J. S. Brush,* Memphis, Tenn.

8. Parathyroid Function following Renal Transplantation in Man. C. D. Arnaud, W. J. Joh nson,* A. Fournier,* and C. F. Anderson,* Rochester, Minn.

\section{PULMONARY}

\section{7:30 p.m., Solarium, Haddon Hall \\ Dr. Kenneth M. Moser, Presiding}

1. The Effect of $[\mathrm{H}+]$ on the Pulmonary Arterial/Alveolar Pressure Relationship. R. LOPEZ-Muniz,* P. HaRSANyi,* T. Macnamara,* and P. G. Rhodes, ${ }^{* *}$ Washington, D. C.

2. Effect of Alveolar Hypoxia on Canine Pulmonary Artery Blood Volume. M. L. Lewis and C. E. Herrara,* New York.

3. The Mechanism of Arterial Hypoxemia following Autologous In Vivo Pulmonary Thrombo-Embolism. Steven E. Levy and Daniel H. Simmons,** Los Angeles, Calif.

4. Altered Pulmonary Mechanics in Angina Pectoris. CARL J. Pepine* and Leslie Wiener,* Philadelphia, Pa. (introduced by Albert N. Brest).

5. The Relation of Extravascular Water to Gas Exchange and Pressures in Pulmonary Edema. Nicholas E. O'Connor, Jaen-Min Sheh,* Robert H. Bartlett, and Harry Bass, Boston, Mass.

6. The Effect of $\mathrm{K}+$ Depletion on Adaptation to Acute and Chronic Hypercapnia. Dwight MAKofF* and BARRY Rosenbaum, Los Angeles, Calif.

7. Cytoplasmic and Mitochondrial. Redox State of the Alveolar Macrophage. Sheldon Mintz* and Eugene D. RoBin,** Pittsburgh, Pa.

8. Pre- and Post-Mortem Dissolution Rate of Pulmonary Emboli in the Dog. K. M. Moser, M. Guisan,* and P. Harsanyi,* La Jolla, Calif. 


\section{RENAL AND ELECTROLYTES I}

7:30 p.m., Viking Room, Haddon Hall

Dr. Laurence E. Early, Presiding

1. Spirolactone Inhibition of Aldosterone Induced Nuclear RNA Synthesis in Toad Urinary Bladder. JACK $\mathrm{H}$. Hutchinson* and George A. Porter, Portland, Oregon.

2. Effects of Acute and Chronic Salt Loading on the Distribution of Renal Cortical Blood Flow. J. L. McNay and Y. ABE,* Atlanta, Ga.

3. Sodium Reabsorption by the Proximal Tubule of Dogs with Aorta to Vena Cava Fistula. Edward G. Sch neider,* Thomas P. Dresser,* Robert E. Lynch,* and Franklyn G. Knox,* Columbia, Mo. (introduced by Douglas M. Griggs**).

4. Micropuncture Study of Electrolyte Transport in Remnant Kidney of the Dog. J. H. Dirks, R. L. Evanson,* E. A. Lockhart,* N. L. M. Wong,* and S. F. Wen, Montreal, Canada.

5. Increased Proximal Tubular Permeability during Renal Vein Constriction. W. E. Yarger,* H. S. Aynedjian,* and N. BANk,* New York.

6. Micropuncture Study of Chronic Obstructive Nephropathy. D. R. Wilson, Toronto, Canada.

7. A Comparison of the Ionic Characteristics of ATPase in the Red Cell, Renal Cortex and Medulla. C. H. Cole and J. H. Dirks, Montreal, Canada.

8. Relationship of Phosphoglycerate Kinase to Hypermetabolism in Erythrocytes in Uremia. C. H. Wallas,* and L. G. Welt, ** Chapel Hill, N. C.

\section{RENAL AND ELECTROLYTES II}

\author{
7:30 p.m., West Room, Haddon Hall \\ Dr. Darrell D. Fanestil, Presiding
}

1. Exaggerated Natriuresis in the Hypothyroid Rat. E. W. Holmes, JR., ${ }^{*}$ and V. A. DiScala, Staten Island, N. Y., and New York.

2. Natriuretic Effect of Insulin. R. S. Hoffman,* J. A. Martino, and R. A. ARKy, Boston, Mass.

3. Effect of Hematocrit on Renal Hemodynamics and Sodium Excretion. R. W. Schrier and L. E. EArLy, San Francisco, Calif.

4. Metabolic Alterations in Rat Renal Cortex following Extracellular Volume Expansion. H. J. KRAMER* añd H. C. Gonick, Los Angeles, Calif.

5. Effect of Hypercalcemia on Proximal Tubule Sodium Reabsorption in the Rat. G. F. DiBona, Iowa City, Iowa.

6. Improvement in Parathyroid Hormone and Calcium Concentrations following Initiation of Hemodialysis. J. W. Johnson,* R. H. Hattner,* L. M. Sherwood, C. L. Hampers, D. S. Bernstein,** and J. P. Merrill,** Boston, Mass.

7. Mechanism of Propionate Stimulation of Sodium Transport in Toad Bladder. I. Singer, M. M. Civan, and G. W. G. Sharp,* Boston, Mass.

8. Adaptation of $\mathrm{K}$ Excretion in Uremia : Evidence for an Unidentified Control Factor. D. TAGgart,* R. Schultze, H. Shapiro,* J. Pennell,* S. Caglar,* and N. Bricker,** St. Louis, Mo.

\section{SUNDAY EVENING, MAY 3}

\section{SUBSPECIALT Y M EET INGS}

(The presentation of each paper will be limited to $10 \mathrm{~min}$. )

\section{CARDIOVASCULAR I}

\section{8:00 p.m., Pennsylvania Room I, Haddon Hall \\ Dr. Edmund H. Sonnenblick, Presiding}

1. Left Ventricular Failure in Acute Myocardial Infarction: Hemodynamic Effects of Glucagon. G. DiAmond,* J. Forrester,* R. DAnzig,* W. Parmley, and H. J. C. Swan, ${ }^{* *}$ Los Angeles, Calif.

2. Effects of Preconditioning on Acute Coronary Occlusion in Awake Dogs. F. R. Совв,* R. J. Комісн,* L. M. Fox,* and B. L. FArIss,** Tacoma, Wash.

3. Site of Heart Block in Acute Myocardial Infarction. Kenneth M. Rosen, Henry S. Loeb, S. H. Rahimtoola,* and Rolf M. Gunnar,** Chicago, Ill.

4. Effect of Heparin on Ventricular Arrhythmias following Myocardial Infarction. J. V. Russo,* S. MARGolis, and R. S. Ross,** Baltimore, Md.
5. Left Ventricular Function in Clinically Uncomplicated Myocardial Infarction. D. Hunt,* C. Potanin,* J. Ромво,* R. O. Russell, JR., and C. E. Rackley, Birmingham, Ala.

6. Inert Gas Quantitation of Average and Regional Coronary Blood Flow. F. J. KLocke, S. M. WittenberG,* A. Drakonakis,* P. Gandel,* and J. Visco,* Buffalo, N. Y.

\section{CARDIOVASCULAR II}

8:00 p.m., Pennsylvania Room II, Haddon Hall

Dr. Edgar Haber, Presiding

1. Comparison of Models for Measurement of Right Ventricular Volume. C. B. Mullins, D. C. Jones,* and W. A. Freeborn,* Dallas, Tex.

2. Factors Affecting Ventricular Function during Cardiac Pacing. W. M. Daggetr, J. A. Bianco,* W. J. Powell, and W. G. Austen,* Boston, Mass. 
3. Effects of Heart Block and Changes in Ventricular Rate on Regional Blood Flow Distribution in the Conscious Dog. C. B. Higgins,* S. White,* S. Vatner,* T. Patrick,* D. McKown,* D. Franklin,* and E. Braunwald, La Jolla, Calif.

4. Effects of Acute Changes in Preload and Afterload on Motion of the Left Ventricle. A. J. Liedtke,* A. Pasternac,* E. H. Sonnenblick, and R. Gorlin,** Boston, Mass.

5. Effect of Increasing Afterload on Left Ventricular Performance. E. Rolett and K. Völlm,* Chapel Hill, N. C.

6. Left Ventricular Performance and Oxygen Consumption in the Hypertrophied, Blood Perfused, Isolated, Supported, Rat Heart. A. E. Kumar,* R. Plenge,* W. J. Gamble,* and R. G. Monroe,* Boston, Mass. (introduced by C. A. Janeway).

\section{DERMATOLOGY}

\section{8:00 p.m., West Room, Haddon Hall \\ Dr. D. Joseph Demis, Presiding}

1. Sebaceous Gland Response in Man to Total Caloric Deprivation. P. E. PochI, D. T. Downing, ${ }^{*}$ and J. S. Strauss, ${ }^{* *}$ Boston, Mass.

2. Skin Insensible Water Loss: Predictable Regulation by Environmental Factors which Influence Diffusion and Evaporation. W. M. Carleton* and B. E. Welch,* Brooks AFB, Tex. (introduced by F. Lecocq).

3. Observations on the Pathogenesis of Sea Nettle Lethal Toxin. R. Goldner* and J. W. Burnett, Baltimore, Md.

4. Pemphigoid Antibody : Its Role in Disease. W. Mitchell Sams, JR., and Gerald J. Gleich, Rochester, Minn.

5. Penicillin Skin Test Reactivity in Patients with Atopy. W. K. Blaylock and Peter F. Hoffman,* Richmond, Va.

6. Nuclear Changes During UV Induced Depression of RNA and Protein Synthesis in Human Epidermis. K. Wier,* K. Fukuyama,* and W. L. Epstein,** San Francisco, Calif.

\section{ENDOCRINOLOGY}

\section{8:00 p.m., Carolina Room, Chalfonte \\ Dr. Jesse Roth, Presiding}

1. Diminished Forearm Glucose Uptake in Man at Bed Rest. R. Lipman, J. Schnure, T. Love,* and F. Lecoco, San Antonio, Tex.

2. "Big" Insulin: Circulating Proinsulin. B. Sherman,* P. Gorden, J. Roth, and J. Gliemann,* Bethesda, Md.

3. Immunoreactive Secretin in an Islet Cell Tumor. S. Cataland,* R. M. Zollinger,* J. E. Jesseph,* J. M. George, and T. G. Skillman,** Columbus, Ohio.
4. Hypothalamic Hyperglycemia-Dissociation of Neural and Hormonal Components. L. A. Frohman and L. L. Bernardis,* Buffalo, N. Y.

5. Plasma Arginine Vasopressin in the Inappropriate $\mathrm{ADH}$ Syndrome. G. BaumanN* and J. F. Dingman, ** Boston, Mass.

6. "Inappropriate" ADH Syndrome with Hyponatremia Induced by Thiazide Diuretics. M. Fichman, C. R. KleemAN,** H. Vorherr,* and N. Telfer, Los Angeles, Calif.

\section{GASTROENTEROLOGY}

\author{
8:00 p.m., Windsor Room, Haddon Hall
}

Dr. Graham H. Jeffries, Presiding

1. Incorporation of Leucine into Immunoglobulins by Jejunal Biopsies of Patients with Celiac Sprue. P. M. Loeb, * W. Strober, and L. Laster, Bethesda, Md.

2. Intestinal Peptide Hydrolases: Differences between Brush Border and Cytoplasmic Enzymes. W. D. Heizer* and K. J. Isselbacher, ** Boston, Mass.

3. Intestinal Sucrase: In Vivo Synthesis and Degradation. B. S. Das* and G. M. Gray, Stanford, Calif.

4. The Importance of In Vivo Inhibition of Intestinal Lactase by Sugars in the Pathogenesis of Lactose Intolerance. D. H. Alpers and M. N. Cote,* St. Louis, Mo.

5. Volume Flow, $\mathrm{H}^{+}$Loss and $\mathrm{CO}_{2}$ Tension in the Human Duodenum. D. H. Winship and J. E. Robinson, Milwaukee, Wis., and Columbia, Mo.

6. A Comparison of Intestinal Fluid Production in Response to Cholera Exotoxin and Hypertonic Mannitol. C. H. Halsted,* E. H. Leubbers,* T. M. Bayless, and T. R. Hendrix,** Baltimore, Md.

\section{HEMATOLOGY}

\section{8:00 p.m., Vernon Room, Haddon Hall \\ Dr. Stanley Yachnin, Presiding}

1. Specificity of Monocyte Receptor in Man and Monkey. N. Abramson, E. W. Gelfand,* F. S. Rosen,* J. H. JANDL,** Boston, Mass.

2. Drug Potentiation of Macrophage Function. M. J. Cline, San Francisco, Calif.

3. Studies of Human Platelet Inositides. P. Cohen, M. J. Broekman,* A. Verkley,* J. W. W. Lisman,* and A. Derksen,* Utrecht, Holland, and Boston, Mass.

4. Thrombin-Induced Alterations in Human Platelet Fatty Acid Metabolism. D. Deykin, Boston, Mass.

5. Accelerated Fibrinogen Consumption in Cirrhosis of the Liver. G. Tytgat,* Leuven, Belgium (introduced by C. E. Rubin).

6. Resolution of Pathological Fibrinolysis with Heparin. S. Robboy,* J. Minna,* and R. Colman, Boston, Mass. 


\section{IMMUNOLOGY}

\author{
8:00 p.m., Viking Room, Haddon Hall \\ Dr. Gordon C. Sharp, Presiding
}

1. Opsonizing Antibodies in Antilymphocyte Serum. F. G. Bull,* K. H. Stenzel, and A. L. Rubin,** New York.

2. Mechanisms of Immunosuppressive Action of Antithymus Serum Prepared with Thymic Ribosomal Fraction. H. NAgaya, Durham, N. C.

3. Protective and Disease-Potentiating Effects of Thyroid Antiserum. G. C. Sharp and P. McMaster,* Columbia, Mo., and Bethesda, Md.

4. Rapid In Vitro Detection of Cell Mediated Transplantation Immunity in Humans. J. R. WUNDERLICH* and G. N. Rogentine, Bethesda, Md.

5. Enhancement of Mouse Cardiac Allograft Survival by Specific Antibody. D. K. Hunter,* J. R. RidGes,* and H. R. Holman, $* *$ Palo Alto, Calif.

6. Prevention of In Vitro Expression of Delayed Hypersensitivity by Virus. W. S. IRviN* and C. P. CRAIG,* Columbia, Mo., and Pittsburgh, Pa. (introduced by G. C. Sharp).

\section{METABOLISM}

\section{8:00 p.m., Music Room, Chalfonte}

Dr. DeWitt S. Goodman, Presiding

1. Hormone Effects of Cyclic $3^{\prime}, 5^{\prime}$-AMP Accumulation and Lipolysis during Incubation of Fat Cells. F. Murad, V. Manganiello,* and M. Vaughan,* Bethesda, Md.

2. Cyclic AMP Stimulation of Amino Acid Transport in Bone and Kidney. J. M. Phang and I. W. Weiss,* Bethesda, Md.

3. Effect of Nicotinic Acid on Beta Lipoprotein Metabolism. T. LANGer* and R. I. Levy, Bethesda, Md.

4. The Role of Tertiary Structure in the Biologic and Immunologic Activity of Human Placental Lactogen and Human Growth Hormone. S. Handwerger, ${ }^{*}$ E. Chan,* and L. M. Sherwood, Boston, Mass.

5. Glucose and Lipid Homeostasis in the Absence of Human Growth Hormone. T. J. Merimee, P. Felig, S. E. FineBERG,* and E. Marliss,* Boston, Mass.

\section{NEOPLASTIC DISEASE}

\section{8:00 p.m., Solarium, Haddon Hall \\ Dr. Martin J. Cline, Presiding}

1. Patterns of DNA-Thymine Synthesis in Short-Term Human Tumor Cell Cultures. Samuel Waxman, Carol. Schreiber,* and Victor Herbert, New York.

2. Enzymatic Conversion of Benzo(A) Pyrene to an Ultimate Carcinogen: Hydroxylation vs. DNA Binding. I. Y. Wang,* H. Marver, and T. Crocker,* San Francisco, Calif.
3. Increased Proliferative Rate in IgE Myeloma: IgE Biosynthesis and Tumor Cell Mass. Sydney E. Salmon, O. Ross McIntrye, and Makio Ogawa,* San Francisco, Calif.

4. Human Tumor Cell Kinetics. Lewis M. SchIffer, Pittsburgh, $\mathrm{Pa}$.

5. Clinical and Pharmacologic Studies with Daunorubicin in Acute Leukemia. R. T. Steer,* J. R. Bertino, and W. A. Creasey, New Haven, Conn.

6. Treatment of Chronic Granulocytic Leukemia with Bromodeoxyuridine. William B. KREMER, Donald S. Miller,* and John Laszlo, Durham, N. C.

\section{PATIENT CARE RESEARCH}

\section{8:00 p.m., Garden Room, Haddon Hall Dr. David Werdegar, Presiding}

1. Patient Outcome in an Emergency Room. Robert $H$. Brook and Robert L. Stevenson, Jr. Baltimore, Md. (introduced by John Williamson).

2. Attitudes of White Patients in a University Clinic Toward Black Physicians. K. Deveney,* C. Greer,* B. Pfefferbaum,* and D. Werdegar, San Francisco, Calif.

3. Nurse-Midwife Impact on Neonatal Mortality. BARRY S. Levy,* Frederick S. Wilkinson,* and William M. MARINe, Berkeley, Calif., and Atlanta, Ga.

4. A System for Monitoring High Risk Cardiac Patients during Transportation within the Hospital. JAMES $O$. Taylor,* Charles F. Landers,* Jeffrey D. Chulay,* William B. Hood, JR., and Walter H. Abelmann,** Boston, Mass.

5. Toward a Realistic Health Care Priority for Sickle Cell Anemia. Robert B. Scotr, Richmond, Va.

6. Comparison of Nurse-Practitioner and Physician Clinics. A. N. Bessman,** M. Ishinama,* and L. Miller,* Los Angeles, Calif.

\section{PULMONARY}

\section{8:00 p.m., Pennsylvania Room III, Haddon Hall Dr. Kenneth M. Moser, Presiding}

1. Pathophysiology of Hereditary Emphysema. P. M. Stevens and V. Hnilica,* Houston, Tex.

2. Trachealis Muscle Parameters Measured In Vivo and Resistance to Collapse of the Canine Trachea. B. PALOMBIN ${ }^{*}$ and R. F. CoBurn, Philadelphia, Pa.

3. Protein Synthesis in Lung following Pulmonary Artery Ligation. D. Massaro, H. Weiss, and G. White,* Washington, D. C.

4. Distribution of Pulmonary Blood Flow and Ventilation after Pneumonectomy and Lobectomy in Man. M. Khalil Ali* and John M. Miller, Houston, Tex. 
5. The Physiologic Profile of Long-Term Autotransplanted Canine Lungs. G. M. Tisi, M. J. Trummer,* A. J. Cuomo,* W. L. Ashburn,* and K. M. Moser, La Jolla, Calif.

6. Effect of Glucocorticoids on the Pulmonary Response to Catecholamines. Harry Bass, Charles R. McClave, II,* Joan F. Abramson,* and Jessica Lewis,* Boston, Mass.

\section{RENAL AND ELECTROLYTES}

\section{8:00 p.m., Rutland Room, Haddon Hall \\ Dr. Laurence E. Early, Presiding}

1. Elevated Angiotensin II in Renal Lymph Indicating the Presence of Angiotensin I Converting Enzyme in Kidney Tissue. M. D. Bailie, F. C. Rector, JR., and D. W. Seldin,** Dallas, Tex.
2. Renin Release from the Denervated, Non-Filtering Dog Kidney. Edward H. Blaine,* James O. Davis,* and Russell Prewitt,* Columbia, Mo. (introduced by John F. Maher).

3. Effect of Prostaglandin $E_{1}$ Chlorpropamide and Vasopressin on Cyclic 3'5' Adenosine Monophosphate in Renal Medulla of Rats. N. P. BECK,* J. B. FIELD, and B. Davis, Pittsburgh, $\mathrm{Pa}$.

4. In Vitro Evidence for Cellular Hypersensitivity to Glomerular Basement Membrane Antigens in Human Glomerulonephritis. R. E. RockLIN,* E. J. LEwIs,* and J. R. David,** Boston, Mass.

5. Demonstration of Nephritogenic, Type Independent Antigens in the Plasma Membrane of Group A Streptococci. G. Treser, M. Semar,* I. Sagel,* A. Ty,* and K. LANGE, ${ }^{* *}$ New York.

6. Relation of Renal Gluconeogensis, Glutamate and Production of Ammonia. A. S. Pagliara* and A. D. GoodMAN, Albany, N. Y. 


\title{
The Association of American Physicians
}

\author{
83RDANNUAL MEETING
}

TUESDA Y, MA Y 5

\section{O R N I N G}

9:00 a.m., Pennsylvania Room, Haddon Hall

GENERAL BUSINESS

THE PRESIDENT'S ADDRESS

SCIENTIFIC SESSION

1. Development of Primary Medical Care Programs by University Teaching Hospitals.

A. Issues Related to Student and House Staff Teaching Programs. Eugene VAyda,* New Haven, Conn. (by invitation).

B. Issues Related to Patient Care Services. Joseph L. Dorsey,* Boston, Mass. (by invitation).

2. The Prognostic Significance of Coronary Arteriography. G. C. Friesinger,* E. PAge,* and R. S. Ross,** Baltimore, Md.

3. Intrarenal Perfusion in the Young "Essential" Hypertensive: a Subpopulation Resistant to Sodium Restriction. Norman K. HollenberG* and John P. Merrill,** Boston, Mass.

4. The Microangiopathic Lesions of Diabetes Mellitus: an Evaluation of Possible Causative Factors. T. J. MERIMeE,* M. D. Siperstein,** S. E. FineberG,* and V. A. McKusick,** Baltimore, Md., Boston, Mass., and Dallas, Tex.

5. Role of Hemoglobin Affinity for $\mathrm{O}_{2}$ and Red Cell 2,3DPG in Management of Diabetic Ketoacidosis. A. BELlingham,* J. Detter,* and C. Lenfant,* Seattle, Wash. (introduced by C. A. Finch).

6. Recent Advances in Fabry's Disease. W. Krivit,* R. J. Desnick,* C. A. Mapes,* and C. C. Sweeley,* East Lansing, Mich., and Minneapolis, Minn. (introduced by J. B. Carey, Jr.**).

7. Viral Hepatitis: New Light on an Old Disease. Saul Krugman** and Joan P. Giles,* New York.

\section{A FTERNOON}

2:00 p.m., Pennsylvania Room, Haddon Hall

PRESENTATION OF

THE GEORGE M. KOBER MEDAL

TO DICKINSON W. RICHARDS

BY

\author{
ANDRE COURNAND
}

SCIENTIFIC SESSION

(continued)

8. Stimulation of Mammalian Erythropoiesis by Metabolites of Steroid Hormones. R. D. Levere,* A. S. Gordon,* E. D. Zanjani,* and A. Kappas,** New York.

9. Blood Hypercoagulability and Thrombosis. Anthony P. Fletcher* and Norma Alkjaersig, ${ }^{*}$ St. Louis, Mo. (introduced by Carl V. Moore**).

10. Consumption-Coagulopathy in Kassabach-Merritt Syndrome. F. Rodriguez-Erdmann,* J. E. Murray,* and W. C. Moloney, ${ }^{* *}$ Boston, Mass.

11. Beta-Carotene as a Photoprotective Agent in Erythropoietic Protoporphyria. M. M. Mathews-Roth,* M. A. Pathak,* T. B. Fitzpatrick,* L. C. Harber,* and and E. H. KAss,** Boston, Mass., and New York.

12. Tissue Assay of Human Protein Malnutrition Using Scalp Hair Roots. R. G. Crounse,* A. J. Bollet,** and S. Owens,* Augusta, Ga.

13. Effect of Large Amounts of Dietary Glutamic Acid upon Serum Lipids and Sterol Metabolism in Man. Robert E. Olson,** Gaetano Bazzano,* and John D'Elia,* St. Louis, Mo.

14. On the Mechanism of Action of Atromid-S on Triglyceride Transport in Man. E. L. Bierman,** D. Porte, Jr.,* and J. D. Brunzell,* Seattle, Wash. 
WEDNESDAY MORNING, MAY 6

9:00 a.m., Windsor Room, Haddon Hall

ELECTION OF OFFICERS AND NEW MEMBERS

THE DISTINGUISHED LECTURE

INBORN AND ACQUIRED ABNORMALITIES OF

THE COMPLEMENT SYSTEM IN MAN

BY

K. FRANK AUSTEN

SCIENTIFIC SESSIONS

(concluded)

15. Pharmacologic Inhibition of the Release of the Chemical Mediators Elicited by the Interaction of IgE Antibodies with Specific Antigen. R. P. Orange,* T. Ishizaka,* K. Ishizaka,* W. J. Koopman,* and K. F. Austen,** Boston, Mass., and Denver, Colo.

16. Hormonal Effects on Extracellular Cyclic Nucleotides in Man. N. I. Kaminsky,* J. H. Ball,* A. E. Broadus,*
J. G. Hardman,* E. W. Sutherland,* and G. W. LidDLE,** Nashville, Tenn.

17. Arrest of Hyperparathyroid Bone Disease by the Use of Dihydrotachysterol in Patients Undergoing Chronic Hemodialysis. Michael Kaye,* G. Chatterjee,* G. F. CoHen,* and S. SAgar,* Montreal, Canada (introduced by Douglas G. Cameron**).

18. Treatment of Osteoporosis with Calcium Infusions. Meyer D. Lifschitz,* Charles Y. C. Pak,* Dorothy Henneman,* Jenifer Jowsey,* and Frederic C. BartTER,** Bethesda, Md., Raritan, N. J., and Rochester, Minn.

19. A Mechanism for Cartilage Destruction in Rheumatoid Arthritis. E. D. Harris, JR.,* D. R. DiBona,* and S. M. Krane,* Boston, Mass. (introduced by A. Leaf**).

20. Demonstration of a Low Molecular Weight Natriuretic Factor in Uremic Serum. J. Bourgorgnie,* F. WeISSER,* D. Rolf,* S. Klahr, and N. S. Bricker,** St. Louis, Mo.

(Time permitting)

21. How to Weigh an Elephant: Cytochrome Oxidase as a Rate Limiting Step in Mitochondrial $\mathrm{O}_{2}$ Consumption. Eugene D. Robin** and Lawrence M. Simon,* Pittsburgh, $\mathrm{Pa}$. 


\section{Exhibitors}

Booth No.

I2 Academic Press Inc.

H2 Advanced Instruments, Inc.

H10 Amicon Corporation

E10 Appleton-Century-Crofts

C8 Behring Diagnostics, Inc.

I3 Bio-Science Laboratories

J2 Brookline Instrument Co.

F9 Cambridge Nuclear Corp.

G4 Warren E. Collins, Inc.

D2, D3 Coulter Electronics, Inc.

G8 F. A. Davis Company

H3, H4 Electronics for Medicine, Inc.

G9 Excerpta Medica Foundation

B6 Farrand Optical Co., Inc.

E5 Gilford Instrument Laboratories, Inc.

G2 Grune \& Stratton, Inc.

C4 Harper \& Row Publishers, Medical DEPARTMENT

I4 Institute For SCIENTIFIC INFormation

F2, F3 Instrumentation Associates, Inc.

J4, J5 Instrumentation Laboratory Inc.

G3 Intercontinental Medical Book Corp.

L5 Kallestad Laboratories, Inc.

B2 Kalmedic Instruments, Inc.

H9 Lamb Engineering Associates

E4 Lea ANd Febiger

C1 E. LeItz, InCORPORATED
Booth No.

C3 J. B. Lippincott Company

C2 Little, Brown and Company, Medical Division

F4 The London Company

A8 The Macmillan Company

E6 Med-Science Electronics, Inc.

D5 Mennen-Greatbatch Electronics, Inc.

A2 The C. V. Mosby Company

I8 New England Nuclear, Biomedical Assay LABoratories Division

I10, J10 Nikon, Inc., Division of Ehrenreich Photo-Optical Industries, Inc.

B5 Oxford University Press, Inc.

B8, B9 Packard Instrument Co., Inc.

J7 Phipps \& Bird, Inc.

C5, C6 Polaroid Corporation

F8 James Addison Potter

D4 Precision Systems

D7 Rockland, Inc.

E2, E3 W. B. Saunders Company

H8 Ivan Sorvall, Inc.

B4 Swifta Data Retrieval Company

D9 Technicon Corporation

C9 Voiceprint Laboratories, Division of FARRINGTON MFG. Co.

E7 The Williams \& Wilkins Co.

A10 Year Book Medical Publishers

Special Area Coca-Cola USA 